\title{
nature
}

12 May 2005 Volume 435 Issue no 7039

\section{Blair's failure}

Britain's research base is flourishing, and Tony Blair's last two governments can take much of the credit for it. But his third needs to focus on the troubled state of the universities.

W hen the Labour party came to power in Britain in 1997, it inherited a decaying science base staffed by disillusioned scientists. The fact that the country's main science lobbying group has recently changed its name from Save British Science to the Campaign for Science and Engineering (CaSE) says much about what the government has achieved since then. When the science minister David Sainsbury and his two opposition counterparts met for a press briefing last month, the spokesmen for both the Liberal Democrats and the Conservatives began by congratulating the Labour government for its record on science.

This lack of conflict was one reason why science played such a minor role in last week's UK elections. But although Labour has indeed performed impressively on this front, there are noticeable gaps in its record. Scientists and their organizations need to put pressure on Tony Blair's administration as it enters a third term in office.

Credit where it is due. Funding for science in universities and the research councils, the main source of UK grants, is up by more than $80 \%$ at $£ 4.3$ billion (US $\$ 8.1$ billion) annually since 1997 and is set to go on rising. Wisely, the critical problem of the nation's crumbling science infrastructure was tackled first. Sainsbury has consistently proved himself to be an enthusiasticscienceminister with well-tuned instincts for policies that are both sound and deliverable.

He has been greatly aided by the championship for science and associated wealth creation by the chancellor of the exchequer, Gordon Brown, who is widely expected to take over from Blair as prime minister within the next four years. The government has also employed a chief science adviser, David King, who has won the respect of researchers and the media and the ear of senior politicians.

Yet many UK scientists say it is as hard as ever to fund the basic research they want to do. Although more money is available, an increasing proportion of it is directed towards specific outcomes, and the freedom to fund responsively in some disciplines is succumbing to other priorities. CaSE calculates that the proportion of science funds controlled by central government has risen from $2 \%$ to $20 \%$ since 1997 — but that the funds available to the key funding agency for the great majority of physicists and chemists, the Engineering and Physical Sciences Research Council, have risen byonly $6 \%$.

The government also faces a bigger challenge: how to reach the ambitious target, set last year, of raising total spending on research and development from $1.9 \%$ to $2.5 \%$ of gross domestic product by 2014. Everyone agrees that the gap must be made up predominantly byindustry - everyone, that is, but industry itself, which, apart from the biomedical sector, by and large persists with a chronic lack of interestin research and is in long-term decline in several manufacturing sectors. Tax breaks and other measures announced last year will help, but many doubt whether the goal can be met. The government needs to abandon the target or explain how to meet it.

The continuing growth of biology-based industries will help, as will a focus on emerging and potentially research-intensive industries such as renewable energy. A drive towards applied research into lowcarbon energy technologies could help bridge the gap between UK academics and thenumerous small firms that work in this area.

But the scandal of the Blair government's record on science is to be found in the universities. There has been a haphazard response to the combination of declining interest among the young in science as a career — not unique to Britain — and misguided university funding schemes. The rise in the grant-funding science budget has not been accompanied by appropriate infrastructural and teaching support from higher-education funding councils. The latter have been too selective in favour of top-rated departments and have exposed the high costs of science departments to increasingly market-driven management. Behind it all lies a lack of joined-up government in addressing the supply and demand for future researchers. Meanwhile, the stream of department closures in the physical sciences is set to continue, to the increasing alarm of industry.

The balance between the freedom of universities to control their development and thenation's need to protect its knowledge and skills base is a delicate one. A critical weakness lies in the Department for Education and Skills, which is often criticized for a lack of responsiveness and excessive control. But it ultimately lies with Blair to ensure that the departments responsible for universities work coherently. In relation to science, this has been his most signal failure.

\section{Proposals, please}

You have one more month to submit proposals for ESOF2006, a fledgling but important forum for European science.

A 11 credit to the small band of Europhile scientists behind the organization EuroScience. After a rush of blood to their heads, and with some skilled salesmanship, they overcame inertia, scepticism and indifference to launch in 2004 the first EuroScience Open Forum (ESOF).

The meeting attracted funding from foundations and the European Commission, and was supported by participants at the heart of European science, both individuals and institutions, including Nature. It attracted more than 1,800 participants from 67 countries, with 250 speakers, 50 sessions and 350 journalists. Feedback suggested that it achieved immediacy, relevance and comprehensibility, in topics ranging from neuroscience to cosmology, and from research policy to science in schools.

The next meeting will be held in Munich, Germany, in July next year. It deserves to thrive but can only do so if Europe's scientists and citizens submit proposals. These should bring unusual collections of panellists together to address hot topics — leading perhaps to scenes like those last year, when sessions overflowed with people wanting to hear debates on climate change.

Those who, like Nature, wish to propose sessions can find the themes of ESOF2006 and submission forms at www.esof2006.org. The deadline for proposals is 15 June. 